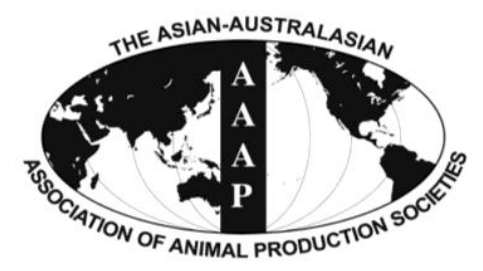

Asian-Aust. J. Anim. Sci.

Vol. 25, No. 7 : 971 - 979

July 2012

www.ajas.info

http://dx.doi.org/10.5713/ajas.2012.12053

\title{
Effects of Protein Level and Mangosteen Peel Pellets (Mago-pel) in Concentrate Diets on Rumen Fermentation and Milk Production in Lactating Dairy Crossbreds
}

\author{
T. Norrapoke, M. Wanapat* and S. Wanapat ${ }^{1}$ \\ Tropical Feed Resources Research and Development Center (TROFREC), Department of Animal Science, \\ Faculty of Agriculture, Khon Kaen University, Khon Kaen 40002, Thailand
}

\begin{abstract}
Four, lactating dairy crossbreds $(50 \% \times 50 \%$ Holstein Friesian $\times$ Native Zebu cattle) were randomly assigned according to a $2 \times 2$ factorial arrangement (two protein levels and two levels of mangosteen peel pellets (Mago-pel)) in a $4 \times 4$ Latin square design to receive four dietary treatments. All cows received concentrate at a proportion of $1 \mathrm{~kg}$ concentrate per $2 \mathrm{~kg}$ of milk yield, and urea-treated $5 \%$ rice straw (UTRS) was given ad libitum. It was found that total dry matter intakes, nutrient digestibility, ruminal $\mathrm{pH}^{2}$ and $\mathrm{NH}_{3}-\mathrm{N}$ concentrations were not affected $(\mathrm{p}>0.05)$ by treatments. Concentrations of ruminal $\mathrm{pH}$ and $\mathrm{NH}_{3}-\mathrm{N}$ were not affected by dietary treatments although the concentration of BUN varied significantly $(\mathrm{p}<0.05)$ between protein levels $(\mathrm{p}<0.05)$. The populations of rumen bacteria and fungal zoospores did not differ among treatments $(p>0.05)$; however, the population of protozoa was decreased $(p<0.05)$ when cows received Mago-pel supplementation. The composition of the population of bacteria, identified by real-time PCR technique, including total bacteria, methanogens, Fibrobacter succinogenes and Ruminococcus albus was similar ( $\mathrm{p}>0.05$ ) among dietary treatments ( $>0.05$ ); however, copy numbers of Ruminococcus flavefaciens was increased when protein level increased ( $<<0.05$ ). Microbial protein synthesis, in terms of both quantity and efficiency, was enriched by Mago-pel supplementation. Milk yield was greatest in cows fed UTRS based diets with concentrate containing protein at 16\% CP with Mago-pel, but were lowest without Mago-pel $(\mathrm{p}<0.05)$. In addition, protein level and supplementation of Mago-pel did not affect ( $>0.05)$ milk composition except solids-not-fat which was higher in cows fed the diet with $19 \%$ CP. Therefore, feeding a concentrate containing $16 \%$ CP together with 300 g/hd/d Mago-pel supplementation results in changes in rumen fermentation and microbial population and improvements in milk production in lactating dairy crossbreds fed on UTRS. (Key Words: Protein Level, Mangosteen Peel Pellets, Rumen Fermentation, Milk Production, Dairy Crossbreds)
\end{abstract}

\section{INTRODUCTION}

Currently, there is increasing interest in exploiting natural products as feed additives to solve problems in animal nutrition and livestock production (Wanapat et al., 2000a). Plant secondary compounds such as condensed tannin (CT) or saponins (SP) are able to impede the ruminal digestion of protein by forming reversible complexes with proteins and ultimately contribute to by-pass proteins for ruminants (Perez-Maldonado and Norton, 1996; McNeill et al., 1998). Furthermore, decreasing ruminal degradation of protein will result in decreased ruminal ammonia

\footnotetext{
* Corresponding Author: Metha Wanapat. Tel: +66-43-202368, Fax: +66-43-202368, E-mail: metha@kku.ac.th

${ }^{1}$ Department of Plant Science and Natural Resources, Faculty of Agriculture, Khon Kaen University, Khon Kaen 40002, Thailand. Submitted Jan. 31, 2012; Accepted Mar. 15, 2012; Revised Mar. 31, 2012
}

concentrations which could negatively impact on microbial growth and efficiency. Tannin-protein complexes are stable in the rumen ( $\mathrm{pH} 5.0$ to 7.0$)$; however, the low $\mathrm{pH}$ (2.5 to $3.5)$ in the abomasum as well as the high $\mathrm{pH}(8.0$ to 9.0$)$ in the small intestine can stimulate dissociation for further absorption and utilization (Perez-Maldonado et al., 1995; McNeill et al., 1998).

Tropical plants or wastes containing CT and/or SP are numerous, for example mangosteen peel, guava leaf, and sesban leaf which contain 100,20 to 100 , and $20 \mathrm{gCT} / \mathrm{kg}$ $\mathrm{DM}$, respectively. Mangosteen peel is a fruit by-product containing high levels of CT; as well as SP which also affects rumen fermentation (Poungchompu et al., 2009). Wang et al. (2000) reported that CT and SP exert a specific effect against rumen protozoa while the rest of the rumen biomass remains unaltered. Similarly, Ngamsaeng et al. (2006) found that supplementation with mangosteen 
powder decreased protozoa populations and the calculated methane production. Supplementation with mangosteen peel and soap berry fruit pellet, which are high in CT and SP, have been shown to alter rumen fermentation by lowering the protozoa population and methane production (Sliwinski et al., 2002; Poungchompu et al., 2009). Moreover, Carrula et al. (2005) suggested that the inhibition of methanogenesis by tannins was primarily the result of suppressing fiber degradation. However, the effects of CT and SP in ruminants vary with the type and concentration in the plants (Wanapat et al., 2000b; 2000c). Studies on the effects of protein levels and mangosteen peel pellets have been quite limited. Therefore, this study was undertaken to determine their effects on nutrient digestibility, rumen ecology and milk production in lactating crossbred cows.

\section{MATERIALS AND METHODS}

\section{Animals, treatments, and experimental design}

Four crossbreds $(50 \% \times 50 \%$ Holstein Friesian $\times$ Native Zebu cattle) lactating dairy cows with average live weight of $413 \pm 25 \mathrm{~kg}$ and $120 \pm 21$ DIM (initial milk production of $12 \pm 2 \mathrm{~kg} / \mathrm{cow} / \mathrm{d}$ ) were randomly assigned according to a $2 \times 2$ factorial arrangement in a $4 \times 4$ Latin square. Two protein levels, $16 \%$ and $19 \% \mathrm{CP}$, and two mangosteen peel pellet levels, 0 and $300 \mathrm{~g} / \mathrm{hd} / \mathrm{d}$, were tested. The four dietary treatments were thus: T1) $16 \% \mathrm{CP}$ of concentrate without Mago-pel; T2) $16 \%$ CP of concentrate with Mago-pel 300 $\mathrm{g} / \mathrm{hd} / \mathrm{d}$; T3) $19 \% \mathrm{CP}$ of concentrate without Mago-pel; and T4) $19 \%$ CP of concentrate with Mago-pel $300 \mathrm{~g} / \mathrm{hd} / \mathrm{d}$. Mago-pel products were prepared by combining $99.5 \%$ mangosteen peel meal $99.5 \%$ with $0.5 \%$ cassava starch. After mixing well, then using $5 \mathrm{~kg}$ of the mixtures was combined with $800 \mathrm{ml}$ of and pelleted by machine. Ureatreated rice straw (UTRS) was prepared by pouring $5 \%$ (wt/wt) urea mixed with $100 \mathrm{~kg}$ of water over $100 \mathrm{~kg}$ stacks of RS and then covering with a plastic sheet for a minimum of 10 days before feeding directly to the animals (Wanapat et al., 2009).

All animals were kept in individual pens $(4 \times 6 \mathrm{~m})$, and mineral block and water were available at free choice. The experiment was conducted for four periods, and each period lasted for 21 days. During the first 14 days, all animals were fed on respective treatment diets while during the last 7 days, samples were collected (diets, feces, milk, blood, and rumen fluid). The chemical composition and components of the concentrate and UTRS are shown in Table 1.

\section{Data collection and sampling procedures}

Feeds samples were randomly collected, and fecal samples were taken by rectal sampling from each individual cow during the last 7 days of each period. Composited samples were dried at $60^{\circ} \mathrm{C}$ and ground (1-mm screen using
Table 1. Chemical composition of concentrate and urea-treated rice straw (UTRS) used in the experiment (\% DM)

\begin{tabular}{|c|c|c|c|c|c|}
\hline \multirow{2}{*}{ Ingredients } & \multicolumn{4}{|c|}{ Dietary treatments } & \multirow{2}{*}{ UTRS } \\
\hline & T1 & $\mathrm{T} 2$ & T3 & $\mathrm{T} 4$ & \\
\hline \multicolumn{6}{|l|}{ Feed ingredients } \\
\hline Cassava chip & 50.0 & 50.0 & 48.0 & 48.0 & - \\
\hline Rice bran & 15.0 & 15.0 & 15.0 & 15.0 & - \\
\hline Coconut meal & 12.5 & 12.5 & 14.9 & 14.9 & - \\
\hline Palm kernel meal & 10.0 & 10.0 & 8.7 & 8.7 & - \\
\hline Sunflower oil & 6.0 & 6.0 & 6.0 & 6.0 & - \\
\hline Urea & 2.5 & 2.5 & 3.4 & 3.4 & - \\
\hline Molasses & 2.0 & 2.0 & 2.0 & 2.0 & - \\
\hline Salt & 0.5 & 0.5 & 0.5 & 0.5 & - \\
\hline Sulfur & 0.5 & 0.5 & 0.5 & 0.5 & - \\
\hline Di-calcium & 0.5 & 0.5 & 0.5 & 0.5 & - \\
\hline Premix & 0.5 & 0.5 & 0.5 & 0.5 & - \\
\hline Total & 100 & 100 & 100 & 100 & - \\
\hline \multicolumn{6}{|c|}{ Chemical composition } \\
\hline \multirow[t]{2}{*}{$\mathrm{DM}(\%)$} & 91.2 & 91.3 & 91.0 & 90.1 & 59.8 \\
\hline & \multicolumn{5}{|c|}{$\%$ dry matter --- } \\
\hline $\mathrm{OM}$ & 95.1 & 95.3 & 94.7 & 94.3 & 87.4 \\
\hline Ash & 4.9 & 4.7 & 5.3 & 5.7 & 12.6 \\
\hline $\mathrm{CP}$ & 16.4 & 16.5 & 19.0 & 19.1 & 6.5 \\
\hline $\mathrm{EE}$ & 10.5 & 10.4 & 11.3 & 11.6 & 0.7 \\
\hline NDF & 18.3 & 18.8 & 16.8 & 17.2 & 72.3 \\
\hline $\mathrm{ADF}$ & 16.2 & 15.8 & 15.3 & 16.9 & 52.1 \\
\hline TDN* & 83.0 & 83.0 & 82.4 & 82.4 & 55.1 \\
\hline
\end{tabular}

UTRS = Urea-treated rice straw, DM = Dry matter, OM = Organic matter, $\mathrm{CP}=$ Crude protein, $\mathrm{EE}=$ Ether extract, $\mathrm{NDF}=$ Neutral detergent fiber, $\mathrm{ADF}=$ Acid detergent fiber, $\mathrm{TDN}=$ Total digestible nutrients.

* Calculated values.

Cyclotech Mill, Teactor, Sweden) and then analyzed for DM, ether extract, ash, CP content (AOAC, 1990), NDF, ADF (Van Soest et al., 1991), and acid-insoluble ash (AIA). The AIA was used to estimate digestibility of nutrients as described by Van Keulen and Young (1977). Condensed tannins content in Mago-pel was analyzed by using the vanillin- $\mathrm{HCl}$ method as modified by Wanapat and Poungchompu (2001).

Cows were milked twice daily using a bucket-type milking system, and milk was weighed at each milking period. Milk samples were composited daily, for both the morning and evening milking, and preserved with 2-bromo2 nitropropane-1, 3-dial and stored at $4{ }^{\circ} \mathrm{C}$ until analysed for milk composition (fat, protein, lactose, total solids, and solid-not-fat) by infrared method using Milko-Scan 33 (Foss Electric, Hillerod, Denmark). Milk urea nitrogen (MUN) was determined using Sigma kits \#640 (Sigma Diagnostics, St. Louis, MO, USA).

Rumen fluid was collected by stomach tube connected with vacuum pump at 0 and $4 \mathrm{~h}$ post feeding on the last day of each period. The $\mathrm{pH}$ and temperature of the rumen fluid 
was immediately measured using a portable $\mathrm{pH}$ and temperature meter (HANNA instrument HI 8424 microcomputer, Singapore). Rumen fluid samples were then filtered through four layers of cheesecloth. Samples were divided into three portions; the first portion was used for volatile fatty acids (VFA) and $\mathrm{NH}_{3}-\mathrm{N}$ analysis where $5 \mathrm{ml}$ of $\mathrm{H}_{2} \mathrm{SO}_{4}$ solution ( $1 \mathrm{M}$ ) was added to $45 \mathrm{ml}$ of rumen fluid. The mixture was centrifuged at $1,600 \times g$ for $15 \mathrm{~min}$, and the supernatant was stored at $-20^{\circ} \mathrm{C}$ prior to VFA analyses using high-performance liquid chromatography (HPLC; Instruments by controller water model $600 \mathrm{E}$, water model 484 UV detector, column novapak $\mathrm{C}_{18}$, column size $4 \times 150$ mm, mobile phase $10 \mathrm{mM} \mathrm{H}_{2} \mathrm{SO}_{4}$ (pH 2.5); ETL Testing Laboratory, Inc., Cortland, NY, USA) according to Samuel et al. (1997). The concentration of $\mathrm{NH}_{3}-\mathrm{N}$ was determined using the micro-Kjeldahl method (AOAC, 1990). The second portion was fixed with $10 \%$ formalin solution in sterilized $0.9 \%$ saline solution and then analyzed for total direct count of bacteria, protozoa, and fungal zoospores using the methods of (Galyean, 1989) based on the use of a hemacytometer (Hausser Scientific, Horsham, PA). The last portion was taken to study cultured groups of viable bacteria using the roll-tube technique (Hungate, 1966) for identifying rumen bacteria groups (cellulolytic, proteolytic, amylolytic, and total viable bacteria). A blood sample (about $10 \mathrm{ml}$ ) was drawn from the jugular vein at the same time as rumen fluid sampling, separated by centrifugation at 1,600×g for $10 \mathrm{~min}$ (Table Top Centrifuge PLC-02, USA) and stored at $-20^{\circ} \mathrm{C}$ for subsequent analysis of blood urea nitrogen (BUN) according to the method of Crocker (1967). Urine samples were analyzed for allantoin and creatinine by HPLC as described by Chen and Gomes (1995). The amount of microbial purines absorbed was calculated from purine derivative excretion based on the relationship derived by Chen and Gomes (1995).

Community DNA was extracted from $0.25 \mathrm{ml}$ aliquots of each sample by the $\mathrm{RBB}+\mathrm{C}$ method (Yu and Morrison, 2004), which was shown to substantially increase DNA yields. In total, 16 samples were obtained, belonging to four treatments, four periods and two times of rumen fluid sampling ( 0 and $4 \mathrm{~h}$ post-feeding). The primers used for the real-time quantitative PCR (qPCR) are as follows: Primers for Fibrobacter succinogenes, Fs219f (5'GGTATGGGATGAGCTTGC-3') and Fs654r (5'GCCTGCCCCTGAACTATC-3'), were selected to allow amplification (446-bp product) of all $10 \mathrm{~F}$. succinogenes strains deposited in GenBank. For Ruminococcus albus primers, Ra1281f (5'-CCCTAAAAGCAGTCTTAGTTCG3') and Ra1439r (5'-CCTCCTTG CGGTTAGAACA-3') (175-bp product). Ruminococcus flavefaciens primers, Rf154f (5'-TCT GGAAACGGATGGTA-3') and Rf425r (5'CCTTTAAGACAGGAGTTTACAA-3'), were also selected to allow species-species amplification (295 bp) of all seven
R. flavefaciens strains deposited in GenBank. All these primer sets were previously published by Koike and Kobayashi (2001). Regular PCR conditions for F.succinogenes were as follows: $30 \mathrm{~s}$ at $94^{\circ} \mathrm{C}$ for denaturing, $30 \mathrm{~s}$ at $60^{\circ} \mathrm{C}$ for annealing and $30 \mathrm{~s}$ at $72^{\circ} \mathrm{C}$ for extension (48 cycles), except for the 9 min denaturation in the first cycle and the $10 \mathrm{~min}$ extension in the last cycle. Amplification of 16S rDNA for the other two species was carried out similarly except an annealing temperature of $55^{\circ} \mathrm{C}$ was used. Quantification of total bacteria population, primer and condition, was previously published by Kongmun et al. (2010). Four sample derived standards were prepared from a treatment pool set of community DNA. The regular PCR was used to generate sample derived DNA standards for each qPCR assay. Then the PCR product was purified using a QIA quick PCR purification kit (QIAGEN, Inc., Valencia, CA, USA) and quantified using a spectrophotometer. For each sample derived standard, copy number concentration was calculated based on the length of the PCR product and the mass concentration. Tenfold serial dilution was made in Tris-EDTA prior to real-time PCR (Yu et al., 2005). In total, four qPCR standards were prepared. The conditions of the qPCR assays of target genes were the same as those of the regular PCR described earlier. Biotools QuantiMix EASY SYGKIT (B\&M Labs, S.A., Spain) was used for real-time PCR amplification. All PCRs were performed in duplicate.

\section{Statistical analysis}

The data were analyzed in a $2 \times 2$ factorial arrangement in a $4 \times 4$ Latin square design by analysis of variance using GLM procedure the (SAS, 1996). The results are presented as mean values and standard error of the means. Differences between treatment means were determined by orthogonal contrast. Differences among means with $\mathrm{p}<0.05$ were accepted as representing statistically different.

\section{RESULTS AND DISSCUSSION}

The chemical composition of UTRS and concentrate diets used in the experiment is shown in Table 1. Mago-pel contained $17.7 \%$ CT; therefore, cows received $53.2 \mathrm{~g}$ $\mathrm{CT} / \mathrm{hd} / \mathrm{d}$. The effect of protein levels and Mago-pel on total dry matter intake and nutrient digestibility are shown in Table 2. Feed intakes and nutrient digestibility were not significantly different $(p>0.05)$ among protein levels and Mago-pel supplementation ( $p>0.05$ ). However, digestibility of dry matter, ether extract, and crude protein tended ( $\mathrm{p}=$ 0.056 ) to be higher in Mago-pel supplemented group while fiber digestion (NDF, ADF) tended $(\mathrm{p}=0.051)$ to be lower with Mago-pel supplementation. These results agreed with Pakmaluek et al. (2005) who found that reducing crude protein from 18 to $14 \%$ did not affect voluntary feed intake 
Table 2. Effect of protein level and mangosteen peel pellets (Mago-pel) in concentrate on voluntary feed intake and nutrient digestibility

\begin{tabular}{|c|c|c|c|c|c|c|c|c|}
\hline \multirow{2}{*}{ Items } & \multicolumn{2}{|c|}{$16 \% \mathrm{CP}$} & \multicolumn{2}{|c|}{$19 \% \mathrm{CP}$} & \multirow{2}{*}{ SEM } & \multicolumn{3}{|c|}{ Contrasts $^{1}$} \\
\hline & -MSP & $+\mathrm{MSP}$ & -MSP & $+\mathrm{MSP}$ & & Pro & MSP & Pro $\times$ MSP \\
\hline \multicolumn{9}{|c|}{ UTRS DMI intake } \\
\hline $\mathrm{kg} / \mathrm{d}$ & 5.5 & 6.6 & 5.2 & 6.6 & 0.18 & NS & NS & $*$ \\
\hline$\% \mathrm{BW}$ & 1.4 & 1.5 & 1.3 & 1.6 & 0.03 & NS & NS & $*$ \\
\hline $\mathrm{g} / \mathrm{kg} \mathrm{BW}^{0.75}$ & 60.6 & 69.9 & 56.5 & 70.5 & 1.50 & NS & NS & $*$ \\
\hline \multicolumn{9}{|c|}{ Total DMI intake } \\
\hline $\mathrm{kg} / \mathrm{d}$ & 11.1 & 12.0 & 11.0 & 12.4 & 0.45 & NS & NS & NS \\
\hline$\% \mathrm{BW}$ & 2.7 & 2.8 & 2.6 & 2.9 & 0.10 & NS & NS & NS \\
\hline $\mathrm{g} / \mathrm{kg} \mathrm{BW}^{0.75}$ & 121.7 & 126.9 & 119.1 & 132.7 & 4.44 & NS & NS & NS \\
\hline \multicolumn{9}{|c|}{ Digestibility (\%) } \\
\hline $\mathrm{DM}$ & 57.0 & 57.4 & 56.5 & 58.1 & 3.27 & NS & NS & NS \\
\hline $\mathrm{OM}$ & 61.3 & 61.2 & 60.1 & 62.0 & 3.60 & NS & NS & NS \\
\hline NDF & 50.1 & 50.1 & 40.3 & 38.8 & 5.42 & NS & NS & NS \\
\hline $\mathrm{ADF}$ & 46.8 & 45.2 & 43.6 & 47.0 & 4.64 & NS & NS & NS \\
\hline $\mathrm{EE}$ & 84.6 & 89.9 & 89.9 & 91.7 & 8.30 & NS & NS & NS \\
\hline $\mathrm{CP}$ & 47.4 & 53.7 & 57.7 & 60.1 & 5.63 & NS & NS & NS \\
\hline
\end{tabular}

${ }^{1}$ Pro $=$ Protein, MSP = Mago-pel, Pro $\times$ MSP $=$ Protein $\times$ Mago-pel, DM = Dry matter, OM = Organic matter, NDF = Neutral detergent fiber, ADF = Acid detergent fiber, $\mathrm{EE}=$ Ether extract, $\mathrm{CP}=$ Crude protein. $\mathrm{SEM}=$ Standard error of the means, $\mathrm{NS}=$ Not significant. $* \mathrm{p}<0.05$.

or digestibility in dairy cow fed with TMR. However, insufficient protein may influence rumen fermentation and decrease of nutrient digestibility. Puchala et al. (2005) found that forage containing CT at $0.196 \mathrm{~kg} / \mathrm{d}$ resulted in relatively high intake.

Table 3 shows effects of protein levels and Mago-pel in concentrates on rumen fermentation, and BUN. Ruminal $\mathrm{pH}$, temperature and $\mathrm{NH}_{3}-\mathrm{N}$ concentration were not affected by either the protein levels or Mago-pel supplementation ( $p>0.05)$. This could be due to effect of Mago-pel on protecting the protein, thus ruminal protein degradation did not occur. Rumen $\mathrm{pH}$ at 0 and $4 \mathrm{~h}$ post-feeding were unchanged by dietary treatments and the values were quite stable at 6.7 to 6.8. According to Wanapat (1999), ruminal
$\mathrm{pH}$ of cattle fed on urea-treated rice straw ranges from 6.5 to 7.2, with the optimum level of $\mathrm{pH}$ in the rumen 6.5 to 7.0. However, supplementation of protein levels and Mago-pel in concentrates with high fat did not affect on $\mathrm{NH}_{3}-\mathrm{N}$ in the rumen ( $p>0.05)$. However, Nguyen and Preston (1999) also found rumen $\mathrm{NH}_{3}-\mathrm{N}$ was increased 8 to $18 \mathrm{mg} / \mathrm{dl}$ by adding urea-treated rice straw. Moreover, concentrate containing $19 \% \mathrm{CP}$ tended to higher the in concentration of $\mathrm{NH}_{3}-\mathrm{N}$ (p $=0.06)$. Perez-Maldonado and Norton (1996) reported also that rumen $\mathrm{NH}_{3}-\mathrm{N}$ concentrations were not affected by dietary CT intake which could relate to the lower level of CT used in the experiment. Protein levels and supplementation of Mago-pel had no effect on volatile fatty acids concentrations in the rumen ( $p>0.05)$. Total volatile

Table 3. Effect of protein level and mangosteen peel pellets (Mago-pel) in concentrate diet on ruminal $\mathrm{pH}$ temperature, $\mathrm{NH}_{3}-\mathrm{N}$ concentration, and volatile fatty acids (VFA)

\begin{tabular}{|c|c|c|c|c|c|c|c|c|}
\hline \multirow{2}{*}{ Items } & \multicolumn{2}{|c|}{$16 \% \mathrm{CP}$} & \multicolumn{2}{|c|}{$19 \% \mathrm{CP}$} & \multirow{2}{*}{ SEM } & \multicolumn{3}{|c|}{ Contrasts $^{1}$} \\
\hline & -MSP & $+\mathrm{MSP}$ & -MSP & $+\mathrm{MSP}$ & & Pro & MSP & Pro $\times$ MSP \\
\hline Ruminal pH & 6.7 & 6.7 & 6.7 & 6.8 & 0.06 & NS & NS & NS \\
\hline Temperature & 39.0 & 38.8 & 39.0 & 38.9 & 0.22 & NS & NS & NS \\
\hline $\mathrm{NH}_{3}-\mathrm{N}(\mathrm{mg} / \mathrm{dl})$ & 11.1 & 11.8 & 13.4 & 12.9 & 0.95 & NS & NS & NS \\
\hline BUN (mg/dl) & 9.9 & 9.5 & 13.8 & 14.1 & 0.86 & $* *$ & NS & NS \\
\hline Total VFA (mmol/L) & 106.3 & 107.9 & 102.3 & 105.9 & 4.07 & NS & NS & NS \\
\hline Acetic acid (\%) & 68.9 & 66.8 & 68.1 & 67.3 & 0.82 & NS & NS & NS \\
\hline Propionic acid (\%) & 20.6 & 21.9 & 21.8 & 20.6 & 1.18 & NS & NS & NS \\
\hline Butyric acid (\%) & 10.5 & 11.3 & 10.2 & 12.2 & 1.11 & NS & NS & NS \\
\hline $\mathrm{C} 2$ to $\mathrm{C} 3$ ratio & 3.4 & 3.1 & 3.2 & 3.3 & 0.20 & NS & NS & NS \\
\hline $\mathrm{CH}_{4}(\mathrm{~mol} / 100 \mathrm{~mol})^{2}$ & 29.6 & 28.6 & 28.7 & 29.5 & 0.8 & NS & NS & NS \\
\hline
\end{tabular}

${ }^{1}$ Pro $=$ Protein, MSP $=$ Mago-pel, Pro $\times$ MSP $=$ Protein $\times$ Mago-pel, $\mathrm{SEM}=$ Standard error of the means, NS = Not significant, $* *$ p $<0.01$.

${ }^{2}$ Calculated according to Moss et al. (2000) $\mathrm{CH}_{4}$ production $=0.45$ (acetate)- 0.275 (propionate) +0.4 (butyrate) . 
Table 4. Effect of protein level and mangosteen peel pellets (Mago-pel) in concentrate diet on microbial population in the rumen of lactating dairy crossbreds

\begin{tabular}{|c|c|c|c|c|c|c|c|c|}
\hline \multirow{2}{*}{ Items } & \multicolumn{2}{|c|}{$16 \% \mathrm{CP}$} & \multicolumn{2}{|c|}{$19 \% \mathrm{CP}$} & \multirow{2}{*}{ SEM } & \multicolumn{3}{|c|}{ Contrasts $^{1}$} \\
\hline & -MSP & $+\mathrm{MSP}$ & -MSP & $+\mathrm{MSP}$ & & Pro & MSP & Pro $\times$ MSP \\
\hline \multicolumn{9}{|l|}{ Total direct counts, cell/ ml } \\
\hline Protozoa $\left(\times 10^{5}\right)$ & 4.5 & 3.2 & 4.7 & 3.4 & 0.33 & NS & $*$ & NS \\
\hline Fungi zoospores $\left(\times 10^{5}\right)$ & 3.0 & 2.6 & 2.4 & 2.6 & 0.41 & NS & NS & NS \\
\hline \multicolumn{9}{|c|}{ Grouping of bacteria $\left(\times 10^{6} \mathrm{CFU} / \mathrm{ml}\right)$} \\
\hline Total viable bacteria & 21.0 & 30.8 & 31.5 & 26.0 & 9.75 & NS & NS & NS \\
\hline Cellulolytic bacteria & 8.2 & 9.8 & 9.6 & 10.2 & 2.17 & NS & NS & NS \\
\hline Amylolytic bacteria & 4.4 & 4.6 & 4.2 & 2.9 & 0.66 & NS & NS & NS \\
\hline Proteolytic bacteria & 3.3 & 5.4 & 3.5 & 2.5 & 0.64 & NS & NS & NS \\
\hline
\end{tabular}

${ }^{1}$ Pro = Protein, MSP = Mago-pel, Pro $\times$ MSP = Protein $\times$ Mago-pel, SEM = Standard error of the means, CFU = Colony forming unit, NS = Not significant, $* \mathrm{p}<0.05$.

fatty acids were produced in normal range of 70 to $130 \mathrm{mM}$ in animals fed with roughage based diet (France and Siddons, 1993). The average of acetic acid, propionic acid and butyric acid concentrations in this study were 67.8, 21.2 and $11.1 \%$ of total VFA, respectively which is similar to those reported by Hungate (1966) $(62,22$ and $16 \%$ for acetic acid, propionic and butyric acid proportion in the rumen respectively). Ngamsaeng et al. (2006) found no significant effect ( $p>0.05$ ) of the feeding level of magosteen peel (MSP) on total VFAs and individual VFA concentrations.

The BUN concentration was highest in the cows receiving the $19 \% \mathrm{CP}$ concentrate with $300 \mathrm{~g} / \mathrm{hd} / \mathrm{d}$.

Fungal zoospores population, cellulolytic, amylolytic and proteolytic bacterial groups did not differ $(p>0.05)$ among treatments $(p>0.05)$. However, including Mago-pel in the concentrate decreased the protozoal population. This is similar to the findings of Samuel et al. (1997) who reported that supplementation of $150 \mathrm{~g} / \mathrm{hd} / \mathrm{d}$ of MSP reduced the population of protozoa in the rumen. Ngamsaeng et al. (2006) also suggested that supplementation of mangosteen peel $(100 \mathrm{~g} / \mathrm{DM} / \mathrm{d})$ in cattle can decrease the protozoal population, increase rumen bacteria and maintain the fungal zoospore population.

The accuracy of each qPCR was validated by quantifying known numbers of target species templates (total bacteria, F. succinogenes, $R$. flavefaciens and $R$. albus) and results are presented in Table 5. Then, those templates were used for generated standard curve. In this study, those standard curves showed a highly linear relationship between $c t$ value and known number template dilution with highly correlations value $\mathrm{r}^{2}$ of standard curve in each species as shown in Figure 1. The target DNAs for qPCR were prepared as described earlier for rumen fluid. For each standard a linear regression derived from the $C(T)$ cycle of each DNA dilution and the $\log$ quantity was presented. As obtained, the $r^{2}$ values of the regressions from methanogen total and cellulolytic bacteria were relatively high. Application of qPCR to quantify methanogen, total bacteria, predominant cellulolytic bacteria (16S rDNA) targets revealed that treatments did not have an effect on total bacteria, methanogen, $F$. succinogenes and $R$. albus. In contrast, $R$. flavefaciens was significantly increased $(\mathrm{p}<0.05)$ when cows received 19\% CP $(6.25 \log$ copies $/ \mathrm{ml}$ rumen fluid). When compared among treatments, $R$. flavefaciens was highest in 19\% CP while lowest in 16\% CP

Table 5. Effect of protein level and mangosteen peel pellets (Mago-pel) in concentrate diet on rumen total bacterial methanogen and predominant cellulolytic bacteria using real-time PCR technique

\begin{tabular}{|c|c|c|c|c|c|c|c|c|}
\hline \multirow{2}{*}{ Items } & \multicolumn{2}{|c|}{$16 \% \mathrm{CP}$} & \multicolumn{2}{|c|}{$19 \% \mathrm{CP}$} & \multirow{2}{*}{ SEM } & \multicolumn{3}{|c|}{ Contrasts $^{1}$} \\
\hline & -MSP & $+\mathrm{MSP}$ & -MSP & $+\mathrm{MSP}$ & & Pro & MSP & Pro $\times$ MSP \\
\hline & \multicolumn{8}{|c|}{ 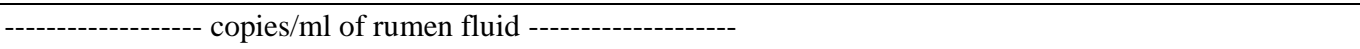 } \\
\hline Total bacteria $\left(\times 10^{9}\right)$ & 2.4 & 1.8 & 2.1 & 3.1 & 0.42 & NS & NS & NS \\
\hline Methanogens $\left(\times 10^{6}\right)$ & 1.1 & 1.1 & 1.2 & 1.3 & 0.13 & NS & NS & NS \\
\hline F. succinogenes $\left(\times 10^{7}\right)$ & 11.6 & 7.6 & 10.2 & 13.0 & 0.84 & NS & NS & NS \\
\hline R. flavefaciens $\left(\times 10^{6}\right)$ & 1.6 & 1.6 & 1.8 & 1.8 & 0.07 & $*$ & NS & NS \\
\hline R. albus $\left(\times 10^{6}\right)$ & 2.6 & 2.5 & 2.6 & 2.6 & 0.08 & NS & NS & NS \\
\hline
\end{tabular}

SEM $=$ Standard error of the means, NS $=$ Not significant, $*$ p $<0.05$.

${ }^{1}$ Pro $=$ Protein, MSP = Mago-pel, Pro $\times$ MSP $=$ Protein $\times$ Mago-pel, SEM = Standard error of the means, CFU = Colony forming unit, NS = No significant, $* \mathrm{p}<0.05$. 


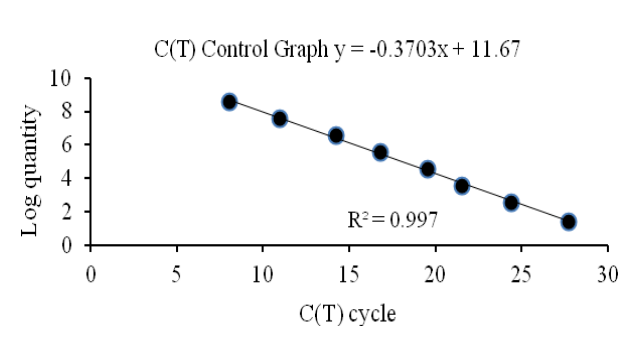

(a)

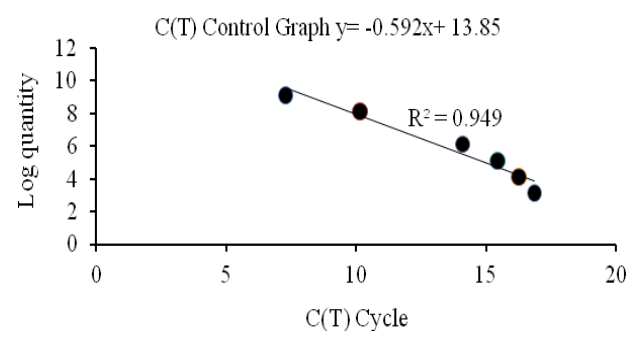

(b)

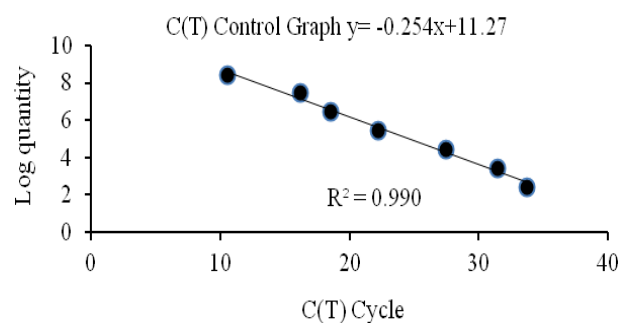

(c)

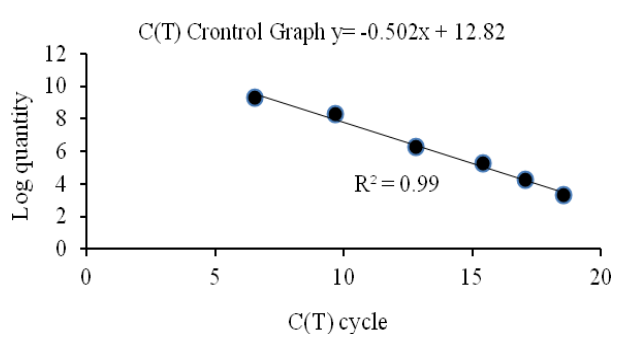

(d)

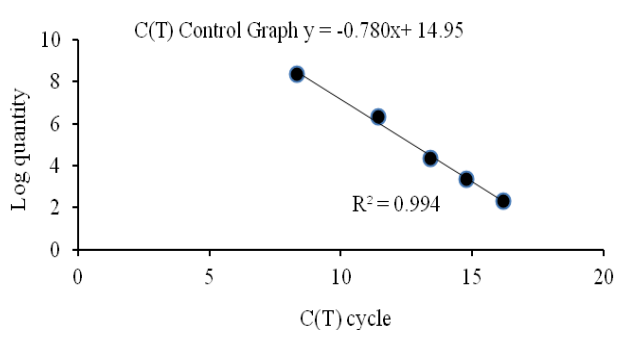

(e)

Figure 1. The standard curves obtained by plotting the logarithm of DNA concentration for total bacteria (a), methanogen (b), $F$. succinogenes (c), R. flavefaciens $(\mathrm{d})$ and $R$. albus (e) versus threshold cycle $(\mathrm{Ct})$ for population quantification by using real time $\mathrm{PCR}$.

diets. Similarly, Wanapat and Cherdthong (2009), who studied rumen cellulolytic bacteria population using realtime PCR, also found that the three cellulolytic bacterial numbers were $3.0 \times 10^{9}, 3.1 \times 10^{7}$ and $2.9 \times 10^{6}$ copies $/ \mathrm{ml}$ of the rumen content for $F$. succinogenes, $R$. flavefaciens and $R$. albus, respectively. Fibolytic species, such as $R$. albus and $R$. flavefaciens, F. succinogenes can digest fiber faster and to a greater extent, in fact, these species even digest crystalline cellulose more actively than ruminococcal species as reported by Koike and Kobayashi (2001).

The effects of protein level and Mago-pel supplementation in lactating dairy cows on the excretion of urinary purine derivatives (PD) and microbial crude protein supply in lactating dairy cows are presented in Table 6. $\mathrm{N}$ balance was significantly different among treatment $(\mathrm{p}<0.05)$. The excretions of creatinine and allantoin

Table 6. Effect of protein level and mangosteen peel pellets (Mago-pel) in concentrate diet on excretion of urinary derivatives and microbial nitrogen supply in lactating dairy crossbreds

\begin{tabular}{|c|c|c|c|c|c|c|c|c|}
\hline \multirow{2}{*}{ Items } & \multicolumn{2}{|c|}{$16 \% \mathrm{CP}$} & \multicolumn{2}{|c|}{$19 \% \mathrm{CP}$} & \multirow{2}{*}{ SEM } & \multicolumn{3}{|c|}{ Contrasts $^{1}$} \\
\hline & -MSP & $+\mathrm{MSP}$ & -MSP & $+\mathrm{MSP}$ & & Pro & MSP & Pro $\times$ MSP \\
\hline Allantoin excretion $(\mathrm{mmol} / \mathrm{d})$ & 199.7 & 291.1 & 215.9 & 283.1 & 8.86 & NS & $* *$ & NS \\
\hline Allantoin absorption (mmol/d) & 150.9 & 242.2 & 166.5 & 234.0 & 8.62 & NS & $* *$ & NS \\
\hline Urine creatinine (mg/dl) & 69.4 & 63.8 & 65.6 & 65.7 & 2.31 & NS & NS & NS \\
\hline $\mathrm{MCP}^{1}(\mathrm{~g} / \mathrm{d})$ & 350.1 & 561.8 & 368.3 & 542.8 & 19.9 & NS & $* *$ & NS \\
\hline EMNS $^{2}$ (g/kg OMDR) & 14.1 & 19.3 & 15.0 & 17.0 & 0.69 & NS & $* *$ & NS \\
\hline
\end{tabular}

SEM $=$ Standard error of the means, NS $=$ Not significant, $* * p<0.01$.

${ }^{1}$ Microbial crude protein $(\mathrm{MCP})(\mathrm{g} / \mathrm{d})=3.99 \times 0.856 \times \mathrm{mmol}$ of purine derivatives excreted (Galo et al., 2003).

${ }^{2}$ Efficiency of microbial nitrogen supply (EMNS), $\mathrm{g} / \mathrm{kg}$ of OM digested in the rumen $(\mathrm{OMDR})=((\mathrm{MCP}(\mathrm{g} / \mathrm{d}) \times 1,000) / \mathrm{DOMR}(\mathrm{g}))$, assuming that rumen digestion $=65 \%$ of digestion in total tract. 
Table 7. Effect of protein level and mangosteen peel pellets (Mago-pel) in concentrate diet on milk yield, milk composition and milk urea nitrogen

\begin{tabular}{|c|c|c|c|c|c|c|c|c|}
\hline \multirow{2}{*}{ Items } & \multicolumn{2}{|c|}{$16 \% \mathrm{CP}$} & \multicolumn{2}{|c|}{$19 \% \mathrm{CP}$} & \multirow{2}{*}{ SEM } & \multicolumn{3}{|c|}{ Contrasts $^{1}$} \\
\hline & -MSP & $+\mathrm{MSP}$ & -MSP & $+\mathrm{MSP}$ & & Pro & MSP & Pro $\times$ MSP \\
\hline Milk yield (kg/d) & 11.1 & 12.7 & 11.2 & 11.5 & 0.18 & $*$ & NS & $*$ \\
\hline $3.5 \%$ FCM $(\mathrm{kg} / \mathrm{d})$ & 11.3 & 12.4 & 11.7 & 12.3 & 0.08 & $*$ & NS & $*$ \\
\hline \multicolumn{9}{|l|}{ Milk composition } \\
\hline Protein & 2.9 & 3.1 & 3.2 & 3.3 & 0.16 & NS & NS & NS \\
\hline Fat & 3.5 & 3.8 & 3.2 & 3.6 & 0.53 & NS & NS & NS \\
\hline Lactose & 4.9 & 4.8 & 5.2 & 5.0 & 0.19 & NS & NS & NS \\
\hline Solids-not-fat & 8.5 & 8.5 & 9.4 & 9.2 & 0.29 & $*$ & NS & NS \\
\hline Total solids & 11.7 & 11.3 & 11.9 & 12.5 & 0.32 & NS & NS & NS \\
\hline MUN (mg/dl) & 10.3 & 11.5 & 13.0 & 11.5 & 1.27 & NS & NS & NS \\
\hline
\end{tabular}

${ }^{1}$ Pro $=$ Protein, MSP $=$ Mago-pel, Pro $\times$ MSP $=$ Protein $\times$ Mago-pel, SEM $=$ Standard error of the means, NS $=$ Not significant, $*$ p $<0.05$.

concentrations in urine were not affected in all treatments. In this regard, the positive $\mathrm{N}$ retention observed in this study indicated the positive influence of protein level with Mago-pel based diet supplements and urea-treated rice straw based feeding systems of lactating dairy cows. With regards to $\mathrm{N}$ utilization, Chen and Gomes (1995) stated that $\mathrm{N}$ excretion and $\mathrm{N}$ retention should reflect differences in $\mathrm{N}$ metabolism, because $\mathrm{N}$ retention was the most important index of the protein nutrition status of ruminants (Ørskov, 1999; Firkins et al., 2007). Microbial efficiencies of the dietary treatments are shown in Table 6. One indicator of the efficiency of rumen nitrogen use is the amount of microbial crude protein (MCP) flow from the rumen, which is a consequence of microbial growth and its washout from the rumen (Weisbjerg et al., 1996). Microbial protein synthesis in the rumen provides the majority of protein supplied to the small intestine of ruminants, accounting for 50 to $80 \%$ of total absorbable protein (Firkins et al., 2007). In the present study, MCP protein flow from the rumen as calculated from purine derivative excretion using the equation (Chen and Gomes, 1995; Galo et al., 2003) ranged from 350.1 to $542.8 \mathrm{~g} / \mathrm{d}$, respectively. Moreover, supplementation of $16 \%$ protein with Mago-pel resulted in the greatest efficiency of microbial $\mathrm{N}$ synthesis (EMNS) (19.3 g N/d). However, ruminal protozoa count was reduced through the addition of MSP in agreement with the our previous work (Pilajun and Wanapat, 2011). The sensitivity of protozoa towards plant secondary compounds may be explained by the presence of sterols in cell membranes (Newbold et al., 1997). This result accorded with the bacterial population from roll-tube technique in which the $16 \%$ protein with Mago-pel and 19\% protein with Mago-pel ratio had the highest and lowest viable bacteria population respectively.

All cows were able to maintain levels of milk yield during the 84 days of the experiment (Table 7). Yield of milk and 3.5\% FCM were greatest in cows fed UTRS based diets with concentrate containing protein at $16 \% \mathrm{CP}$ with Mago-pel, but were lowest when receiving concentrate containing protein at $16 \% \mathrm{CP}$ without Mago-pel. However, Milk yield was also affected by a MSP interaction with CP so that milk yield was higher in the $16 \%$ CP plus MSP than in the $19 \%$ concentrate treatment. In addition, the supplementation of protein levels in concentrate and Magopel did not significantly affect on milk compositions including milk fat, milk protein, lactose and total solid. However, solids-not-fat was higher in cow fed with $19 \% \mathrm{CP}$ than those on $16 \%$ CP (Table 5). Supplementation of Magopel tended to increase milk yield and $3.5 \%$ FCM as compared to non-supplementation group.

\section{CONCLUSIONS AND RECOMMENDATIONS}

Protein level and supplementation of Mago-pel had no effect on feed intake, digestibility of nutrient, and volatile fatty acids; however, blood urea nitrogen was higher in cow receiving concentrate containing $19 \%$ CP. Ruminococcus flavefaciens abundance was impacted by protein levels, while the population of protozoa was decreased by Magopel supplementation. Microbial protein synthesis was improved with Mago-pel supplementation. Milk yields were greatest in cows fed with concentrate containing $16 \% \mathrm{CP}$. Therefore, a combined use of concentrates containing $16 \%$ $\mathrm{CP}$ with supplementation of Mago-pel at $300 \mathrm{~g} / \mathrm{hd} / \mathrm{d}$ could have potential for lactating dairy crossbreds especially when fed on rice straw as a roughage source.

\section{ACKNOWLEDGEMENTS}

The authors would like to express their most sincere thanks to Tropical Feed Resources Research and Development Center (TROFREC), Department of Animal Science, Faculty of Agriculture, Khon Kaen University, Thailand and The Thailand Research Fund in collaboration 
with Khon Kaen University (TRF Master Research Grants: TRF-MAG Window II) for their kind financial support and the use of research facilities.

\section{REFERENCES}

AOAC. 1990. Official methods of analysis. Association of Official Analysis Chemists, DC, USA.

Carulla, J. E., M. Kreuzer, A. Machmller and H. D. Hess. 2005. Supplementation of Acacia mearnsii tannins decreases methanogenesis and urinary nitrogen in forage-fed sheep. Aust. J. Agric. Res. 56:961-970.

Crocker, C. L. 1967. Rapid determination of urea nitrogen in serum or plasma without deproteinzation. Am. J. Med Technol. 33:361-365.

Chen, X. B. and M. J. Gomes. 1995. Estimation of microbial protein supply to sheep and cattle based on urinary excretion of purine derivative-an overview of the technique details. Occasional Publication 1992. International Feed Resources Unit, Rowett Research Institute, Aberdeen, UK.

Fievez, V., F. Piattoni, L. Mbanzamihigo and D. Demeyer. 1999. Reductive acetogenesis in the hindgut and attempts to its induction in the rumen- a review. J. Appl. Anim. Res. 16:1-22.

Firkins, J. L., Z. Yu and M. Morrison. 2007. Ruminal nitrogen metabolism: perspectives for integration of microbiology and nutrition for dairy. J. Dairy Sci. 90(E. Suppl.):E1-E16.

France, J. and R. C. Siddons. 1993. Volatile fatty acid production. In: Quantitative Aspects Ruminant Digestion and Metabolism (Ed. J. M. Forbes and J. France). C. A. B. International, Willingford, UK. 107-122.

Galyean, M. 1989. Laboratory procedure in animal nutrition research. Department of Animal and Life Science. New Mexico State University, USA.

Galo, E., S. M. Emanuele, C. J. Sniffen, J. H. White and J. R. Knapp. 2003. Effects of a polymer-coated urea product on nitrogen metabolism in lactating Holstein dairy cattle. J. Dairy Sci. 86:2154-2162.

Hungate, R. E. 1966. The rumen and its microbes. Academic Press. New York and London.

Kafi, M. and A. Mirzaei. 2010. Effect of first postpartum progesterone rise, metabolites, milk yield, and body condition score on the subsequent ovarian activity and fertility in lactating Holstein dairy cows. Trop. Anim. Health Prod. 42: 761-767.

Koike, S. and Y. Kobayashi. 2001. Development and use of competitive PCR assays for the rumen cellulolytic bacteria: Fibrobacter succinogenes, Ruminococcus albus and Ruminococcus flavefaciens. FEMS Microbiol. Lett. 204:361366.

Kongmun, P., M. Wanapat, P. Pakdee and C. Navanukraw. 2010. Effect of coconut oil and garlic powder on in vitro fermentation using gas production technique. Livest. Sci. 127: 38-44.

McNeill, D. M., N. Osborne, M. Komolong and D. Nankervis. 1998. Condensed tannins in the Leucaena genus and their nutritional significance for ruminants. In: Leucaena-Adaptation, Quality and Farming Systems (Ed. H. M. Shelton, R. C. Gutteridge, B. F. Mullin and R. A. Bray). ACIAR Proceedings.
86:205-214.

Newbold, C. J., S. M. Hassan, J. Wang, M. E. Ortega and R. J. Wallace. 1997. Influence of foliage from African multipurpose trees on activity of rumen protozoa and bacteria. Br. J. Nutr. 78:237-249.

Nguyen Van Thu and T. R. Preston. 1999. Rumen environment and feed degradability in swamp buffaloes fed different supplements. Livest. Res. Rural Dev. 11(3):http:// www.Cipav. Org. co/ieed/Irrd 11/3/thu 113. htm.

Orskov, E. R. 1999. Supplement strategies for ruminants and management of feeding to maximize utilization of roughages. J. Anim. Vet. Adv. 38:179-185.

Pakmaluek, P., C. Wachirapakorn, M. Wanapat and P. Pakdee. 2005. Effect of level of crude protein in Total Mixed Ration (TMR) with corn cobs and rice straw as roughage sources on rumen fermentation, milk yield and composition in lactating dairy cows. KKU Res. J. (GS)5:2.

Perez-Maldonado, R. A. and B. W. Norton. 1996. The effects of condensed tannins from Desmodium intorturn and Calliandra calothyrsus on protein and carbohydrate digestion in sheep and goats. Br. J. Nutr. 76:515-533.

Pilajan, R. and M. Wanapat. 2011. Effect of coconut oil and mangosteen peel supplementation on ruminal fermentation, microbial protein synthesis in swamp buffaloes. Livest. Sci. doi: 10.1016/j.livsci.2011.05.013.

Poungchompu, O., M. Wanapat, C. Wachirapakorn, S. Wanapat and A. Cherdthong. 2009. Manipulation of ruminal fermentation and methane production by dietary saponins from mangosteen peel and soapberry fruit. J. Anim. Nutr. 63:389400.

Puchala, R., B. R. Min, A. L. Goetsch and T. Sahlu. 2005. The effect of a condensed tannin-containing forage on methane emission by goats. J. Anim. Sci. 83:182-186.

Samuel, M., S. Sagathewan, J. Thomas and G. Mathen. 1997. An HPLC method for estimation of volatile fatty acids of ruminal fluid. Indian J. Anim. Sci. 67:805-807.

SAS. 1996. User's guide: Statistic, Version 5. Edition., 1996. SAS. Inst Cary, NC, USA.

Satter, L. D. and L. L. Styler. 1974. Effect of ammonia concentration on ruminal microbial protein production in vitro. Br. J. Nutr. 32:199-208.

Sliwinski, B. J., M. Kreuzer, H-R. Wettatein and A. Machmuller. 2002. Rumen fermentation and nitrogen balance of lambs fed diets containing plant extracts rich in tannins and saponins, and associated emissions of nitrogen and methane. Arch. Anim. Nutr. 56:379-392.

Van Keulen, J. and B. A. Young. 1977. Evaluation of acidinsoluble ash as a marker in ruminant digestibility. J. Anim. Sci. 44:282-287.

Van Soest, P. J., J. B. Robertson and B. A. Lewis. 1991. Methods for dietary fiber neutral detergent fiber, and nonstarch polysaccharides in relation to animal nutrition. J. Dairy Sci. 74:3583-3597.

Wanapat, M. 1999. Feeding of ruminants in the tropicals base on local feed resources. Khon Kaen Publishing Company Ltd., Khon Kaen, Thailand. p. 236.

Wanapat, M. 2009. Potential uses of local feed resources for ruminants. Trop. Anim. Health Prod. 41:1035-1049.

Wanapat, M. and O. Poungchompu. 2001. Method for estimation 
of tannin by vanillin- $\mathrm{HCl}$ method (A modified method of Burns, 1971). Department of Animal Science, Khon Kaen University, Khon Kaen 4002, Thailand.

Wanapat, M., O. Pimpa, W. Sripuek, T. Puramongkol, A. Petlum, U. Boontao, C. Wachirapakorn and K. Sommart. 2000a. Cassava hay: An important on-farm feed for ruminants. In: Tannins in livestock and human nutrition: Proceedings of an international workshop (Ed. J. D. Brooker). Adelaide, May 31June 2, 1999. ACIR. No. 92:71-74.

Wanapat, M., T. Puramongkol and W. Siphuak. 2000b. Feeding of cassava hay for in lactating dairy cows. Asian-Aust. J. Anim. Sci. 13:478-482.

Wanapat, M., A. Petlum and O. Pimpa. 2000c. Supplementation of cassava hay to replace concentrate use in lactating Holstein Friesian crossbreds. Asian-Aust. J. Anim. Sci. 13:600-604.
Wang. Y., T. A. McAllister, L. J. Yanke, Z. J. Xu, P. R. Cheeke and K. J. Cheng. 2000. In vitro effects of steroidal saponins from Yucca schidigera extract on rumen microbial protein synthesis and ruminal fermentation. J. Sci. Food Agric. 80:2114-2122.

Weisbjerg, M. R., T. Hvelplund, S. Hellberg, S. Olsson and S. Same. 1996. Effective rumen degradability and intestinal digestibility of individual amino acids in different concentrates determined in situ. Anim. Feed Sci. Technol. 62:179-188.

Yu, Z., F. C. Michel, Jr., G. Hansen, T. Wittum and M. Morrison. 2005. Development and application of real-time PCR assays for quantification of genes encoding tetracycline resistance. Appl. Environ. Microbiol. 71:6926-6933.

Yu, Z. and M. Morrison. 2004. Improved extraction of PCRquality community DNA from digesta and fecal samples. BioTechniques 36:808-812. 